\title{
The Masculine Sea and the Impossibility of Awakening in Chopin's The Awakening
}

\author{
Abbasi, P. \\ Assistant Professor of English Literature, English Department, Faculty of Foreign Languages, University of Isfahan, Hezar \\ Jerib St., Isfahan, IRAN. Zip code: 0311-8174674331; Tel: 0311-7932985 \& 09379168966. \\ E-mails: Pyeaam77@yahoo.co.uk; abbasi@fgn.ui.ac.ir
}

\begin{abstract}
Kate Chopin has a firm place in American women's writing. A persistent theme in her works is said to be women's emotional liberation. The Awakening (1899) as a feminist novel is no exception. In the novel, Edna's inner voice and desire for escape from a male-dominated society awaken in her. Edna's suicide has been interpreted as her victory over the society however, this study argues that the idea of female defeat has been ignored to a great extent the main reason for which is the ignorance or a misreading of sea imagery. The sea of the novel that dissolves Edna is a signifier of male society and language signifying Edna's failure to find a place within the male dialogue of the society. Extra-marital relationships with Alcee or Robert are not promising, for the climax of such relationships is no more than the old requirement of becoming the good wife and mother that the society prescribes to women. By her ultimate suicidal choice, Edna determines to find a voice and be seen but is totally perished instead to prove that women cannot speak. This study intends to argue and conclude that Chopin had this Kristevaesque belief that the male socio-cultural formation does not let women experience freedom. A new interpretation of the sea as a patriarchal element is offered which makes Edna's drowning a total defeat rather than victory as suggested by many critics.
\end{abstract}

Key words: Kristeva, sea, patriarchy, identity, cultural formation.

\section{INTRODUCTION}

Kate Chopin has a firm place in American women's writing. The reason for this seems to be the persistent theme in her works meaning women's emotional liberation. The Awakening (1899) as a feminist novel is no exception, and explores its protagonist's inner conflicts and desire for selfexpression. Much has been said about Edna's inner voice that awakens in her as well as her desire for escape however, the idea of female defeat has been ignored to a great extent the main reason for which is the ignorance or a misreading of sea imagery. In other words a more exact look at sea imagery-discussed in the first sub chapterwill change the interpretation of the concluding part of the novel or Edna's suicide which many critics have referred to as Edna's victory. I do not agree with Bradley (2005) who emphasizes Edna's victory and refers to "Edna's ... delight" and entering "a world" where she can "negate all patriarchalism" (p. 60). Nor do I see eye to eye with Gray (2004) who interprets Edna's escape and drowning as liberation: "Edna escapes oppressive ideology" (p. 72). Ramos (2010) is not different who concludes that obstacles "could ultimately be overcome" (p. 161). Having read a good number of essays, Ramos refers to a common view that "the patriarchal social pressures forced upon such a woman were either inescapably deterministic or, somehow, entirely avoidable through a kind of mythical rebirth achieved through the act of suicide" (p. 146). Barbara Hochman sees Edna's suicide as "a refusal to reenter the cycle of sexuality and birth that makes the presence of "a little new life" inescapable" (as cited in Pizer, 1999, p. 230). This, again, is an emphasis laid on Edna's independence and active role in resisting the patriarchal system. This study, however, intends to argue and conclude that Chopin had this Kristevaesque belief that women do not and cannot exist. Kristeva who provides her readers with an exact vision of women and their place in the society, discusses the socio-cultural formation of women and concludes that women's chance for existence is very slim. It will be argued that the society and specifically the sea as a shaping force leaves no room for women's true existence.

Kate Chopin can be identified with her protagonist confined within biological and cultural circumstances - marriage and childbearing - with the desperate need to transcend limits through art. Parvulescu (2005) beautifully introduces the novel's tension residing "within a self that lives itself as double," as oscillation between an "outward" life in which one "conforms" and an "inward" life in which one "questions" (p. 478). This introduces the significant idea of women's uncertainty regarding their identities and inner conflicts. In other words Edna remains a divided self and "until the very end painfully struggles and fails to unify these two sides of being [mind and body]" (Church \& 
Havener, 2008, p. 196). The following part discusses that Chopin believed that in the face of restrictions in a patriarchal society and material conditions of patriarchal rule nothing could be done. Even after defying roles of wife and mother, it is impossible to adopt a sustainable identity which leaves Edna morally, emotionally and spiritually empty and senseless. Accordingly this study offers a new interpretation of the sea as a patriarchal element which makes Edna's drowning a totally different experience.

Discussion

\section{The Patriarchal Sea}

The sea is a very important element in the novel regarding Chopin's view of women. A rereading of the novel reveals meanings other than freedom and escape for the sea suggested by many critics. The way the sea is used in the novel makes it the masculine language and a male discourse that dissolves Edna for her trespasses and transgressions: Edna practices swimming and painting in order to change her position in the society and adopt a different identity.

It is important to pay close attention to some lines from the novel: Edna tells her husband "I thought I should have perished out there [sea] alone" (Chopin, 1899, p. 38). Thinking of the sea, Edna "recalled the terror" (p. 156); she feels the "old terror" (p. 157). The sea is always associated with fear and horror, for Edna is afraid of going against the waves (of convention and discourse) and conquering the sea (of male discourses). Early in the novel while at sea, "a quick vision of death smote her soul, and for a second of time appalled and enfeebled her senses" (pp. 37-38). Edna as a construct has always been paralyzed by the sea and shaped by it. The sea comes next to such discourses as the Church, her father and her husband: "How still it was with only the voice of the sea whispering through the reeds .... It must have always been God's day on that low, drowsy island, Edna thought" (p. 48). It is noteworthy that only the sea's voice can be heard and at its presence Edna can only think. Barbara Hochman is one of the critics that believes that "the sea-voice is neither articulate as language nor conducive to differentiation or autonomy" (as cited in Pizer, 1999, p. 218). What matters is the presence of this voice and its dominating quality that robs Edna of speech. "The voice of the sea" is repeated many times in the novel: one instance is "the voice of the sea is seductive; never ceasing, whispering, clamoring, murmuring, inviting the soul to wander for a spell in abysses of solitude; to lose itself in mazes of inward contemplation" (Chopin, 1899, p. 18). After Edna's and her husband's quarrel, the inarticulate Edna starts crying and hears "the everlasting voice of the sea that broke like a mournful lullaby [to Edna as a child] upon the night" (p. 8). In the concluding paragraphs of the novel again Edna's voice is overshadowed by the largerthan-life voice of the sea: "The water of the Gulf stretched out before her, gleaming with the million lights of the sun. The voice of the sea is seductive, never ceasing, whispering, clamoring, murmuring, inviting the soul to wander in abysses of solitude .... A bird with a broken wing ..." (pp. 155-156). The introduction of the "everlasting voice of the sea" in the beginning of the novel (p. 8) and "never ceasing" at the end (p. 155) signifies Chopin's view of women caught within the complex web of socio-cultural discourses from which it is hard to escape, and within which it is hard to speak and quite impossible to be heard.

Edna's attempt to learn swimming as a physical conquest finds double importance here. It is one way to cope with the overwhelming sea but to no avail as the final scene is Edna's drowning: "Edna had attempted all summer to learn to swim" (p. 36). The serpent-like sea is a phallic symbol. At the end of the novel standing naked, Edna feels "the foamy wavelets curled up to her white feet, and coiled like serpents about her ankles" (p. 156); or "most of them walked into the water as though into a native element. The sea was quiet now, and swelled lazily in broad billows that melted into one another and did not break except upon the beach in little foamy crests that coiled back like slow, white serpents" (p. 36). Edna is raped and devoured by the male seductive sea that represents the surrounding reality and pressures of environment, and is intolerant of resistance and a language different from the native language of masculinity. Edna's strength is gone in the sea, and terror fills her whole being. She is silenced at sea and is not able to tell her tale. There she cannot speak and just thinks: "Her arms and legs were growing tired. She thought of Leonce and the children" (p. 156). Edna hears "the hum of bees," and smells "the musky odor of pinks" (p. 157) but no word is produced. It is interesting that in chapter five Chopin refers to the "seductive odor of the sea" (p. 16). Edna's final attempt results only in self-effacement and her selfrepresentation is erased in the sea where the privileging of masculinity over femininity is obvious. The sea is associated with the sun, and femininity with darkness. One instance is the description of the sun and the sea: "the sun was low in the west, and the breeze soft and languorous that came up from the south, charged with the seductive odor of the sea" (p. 16) or "the water of the Gulf stretched out before her, gleaming with the million lights of the sun" (p. 155). Chopin describes that "despondency had come upon her there in the wakeful night, and had never lifted" (p. 155). As Edna goes on "she remembered the night she swam far out, and recalled the terror that seized her at the fear of being unable to regain the shore" (p. 156). Easthope's (1991) words seem related: "masculinity has become privileged as self-present, norm, the knowable, light, the sun, while the feminine ... is constructed as other, deviant, different, unknown, darkness, the moon" (p. 134).

When the sea is mentioned, Chopin brings a bird to suggest entrapment. The motif of caged birds shows that the discourses of the patriarchal society have not provided Edna with strong wings - have not let her shape strong ones - to fly above convention. The final part of the novel shows "a bird with a broken wing" that "was beating the air above, reeling, fluttering, circling disabled down, down to the water" (Chopin, 1899, p. 156). The femininity of the bird is underscored when Edna and Madame Lebrun's parrotexotic birds such as the parrot appear in different parts of the novel—are compared revealing inability to communicate with the world around. It is important to note how Chopin begins her novel: "A green and yellow parrot, which hung in a cage outside the door, kept repeating over and over: "Allez vous-en! Allez vous-en! Sapristi! That's all right!" 
He could speak a little Spanish, and also a language which no body understood" (p. 1). The identification between Edna and the bird signifies inadequacy of female language and the impossibility to communicate. The identification shows Edna as an Icarus figure that flies to liberate herself but to no avail, for it is impossible to flee from the complex maze of patriarchal discourses that have shaped one's wings. One should remember Althusser's (1998) definition of ideology: an "imaginary relation to the real relations of existence" (p. 299). Edna is not and cannot remain outside of power and ideological relations. Chopin shows drowning as the end and result of flying above the web of patriarchal conventions.

\section{Women as Socio-Cultural Constructs}

A number of critics' opinions seems suitable to a new reading of Chopin's novel. Gayatri Spivak is one of the critics who believes in the absence of women's voice as a sign of violence of patriarchy. In her influential "Can the Subaltern Speak?" Spivak suggests that the voice of the subaltern or the oppressed cannot be recovered and heard. Although Spivak has been accused of "deliberate deafness to the native voice where it can be heard," for she "attributes an absolute power to the hegemonic discourse" (as cited in Parry, 1987, p. 39), she is not alone. Julia Kristeva also believes that "strictly speaking women cannot be said to exist" (as cited in Butler, 2007, p. 1). De Beauvoir (1961) in her The Second Sex sees the shaping power of the male condition: "one is not born a woman, but, rather, becomes one" (p. 301) which implies gender construction and how women are socially constructed and conditioned to adopt femininity and otherness.

De Beauvoir's words in The Second Sex are noteworthy: "humanity is male and man defines woman not in herself but as relative to him." She continues that woman "is not regarded as an autonomous being ... she is the incidental, the inessential as opposed to the essential. He is the Subject, he is the Absolute, she is the Other" (p. xvi). This is why Judith Butler (2007) who rejects the normative notion of a social construct, concludes that for Beauvoir women are "designated as the Other" and "the negative of men, the lack against which masculine identity differentiates itself' (p. 13). Chopin shares many of these mentioned ideas - at least in The Awakening - and shows Edna as a negative image who is not recognized in the society. By portraying Edna's death, Chopin has shown that woman as a social construct is not free to change her situation and stand before the male law.

Edna's gender role is constructed through repetition of male practices and discourses that construct subjects and are beyond control. "Human subjects," according to Loomba (2000), "are not fixed essences, but are discursively constituted" (p. 233). The sea as discussed in the previous sub chapter is a striking example of male language which implies that Edna fails to communicate and find a place within the male dialogue of the society. Gender cannot be separated from politics and culture, for according to Butler (2007) "gender intersects with racial, class, ethnic, sexual, and regional modalities of discursively constituted iden- tities" (p. 4). Edna's gender is the cultural means by which she is represented. Indeed Edna's gender is naturalized through repeated male practices that leave no room for Edna's will to make a change. As practices within such a patriarchal system cannot be natural but conditioned by processes of power, Chopin has shown Edna's little chance of violating the norm as well as acting against maledominated ideologies, i. e. the impossibility of awakening. The impossibility of change is due to the discursive formation of identities. Edna is culturally conditioned into womanhood which is why her attempt to seize power and dominate her husband seems useless. The male-dominated society also leaves no space, from a Spivakean point of view, for Edna to speak from as a liberated woman. This reminds us of Beauvoir's belief that "actually, there are very, very few truly liberated women" (as cited in Card, 2003, p. 194). Edna takes care of her husband slave-like, has a secondary role in relation to her husband, and has no chance in any physical or intellectual conquests. The desires to learn swimming and become an artist are, respectively, physical and intellectual conquests she explores in mind providing that she can free herself from the circles of duties imposed by the male society. This means that man is transcendent and "there is no arena where she [woman] can be recognized as a subject." To this De Beauvoir adds the fact that woman's "struggle to become transcendent is ... invariably blocked” (p. 151).

Chopin, herself a subject and discursively-formed construct, is not able to show Edna's independence. Man is shown to be a privileged signified, and male discourse the producer of meaning and history. Chopin's showing Leonce with glasses is an implication of male power and desire to dominate. According to Irigaray, sight is "associated with the male desire to see things clearly and logically and to master them theoretically" (as cited in Rivkin \& Ryan, 2000, p. 573). Cultural compulsion demands submission of femininity and production of masculinity. It is interesting to notice that Edna lives in a capitalist setting or a consumer society that produces men. Therefore the female is colonized and structured by male economic and political developments that is reminiscent of Henry Louis Gates' (1991) suggestion: "all discourse is colonial discourse" (p. 466). The sea as mentioned above-associated with the male world - conquers Edna, dissolves her, and leaves her space outside the patriarchal system. The final act of the novel is Chopin's affirmation of the fact that in order to represent or express herself, Edna must first exist. The disappearance in the sea shows the impossibility of awakening within the very structures of power that have shaped her.

This puts the possibility of a language to represent women under question since subjects are made through language. De Beauvoir believes that language is "constituted through circulation, in the mass of people" (as cited in Card, 2003, p. 193). Edna's vulnerability is shown in the forces beyond her control, and her decision to change herself by learning to swim or trying to become an artist. Throughout the novel the inadequacy of language is, beautifully, shown in such women as Edna and Mme. Ratignolle not understanding each other well. Pizer (1999) states that "Edna Pontellier 
fails to tell her story," except the brief account of the lovers' paddling away in a pirogue never coming back (p. 215). Edna's silence implies that her language has limits. She does not know what to say, or how to say. Since "all language is masculine," Streater (2007) believes, "Edna has no language by which to express an authentic feminine expression and thus she remains silent" (p. 410). Therefore Chopin, in the last scene, confirms the failure of feminine liberation and the impossibility of the subaltern's voice. By her ultimate suicidal choice, Edna determines to find a voice and be seen but is totally perished instead to prove that the subaltern cannot speak.

\section{Interpellation and Identity}

Butler believes that "interpellation" is "the two-way process of hailing or calling a subject into being" and "the subject ... comes into being through the power of interpellation; it is a founding, and potentially imprisoning gesture" (as cited in Lane, 2006, pp. 50-51). Althusser (1998) believes that hegemony acts through "interpellation" which is "the recognition and adoption of an ideology and its practices" (p. 299). Edna wishes to resist interpellations of patriarchal ideologies by violating the wife/mother role. Gray (2004) sees Edna's awakening as exactly Edna's attempt to "temporarily resist the interpellations of patriarchy" (p. 60). Edna is an interpellated subject that is constituted through the male discourses and practices of the society. As a regional stereotype, she has been brought up where men have been dominant and women have been dependent on men for years. Butler (2007) says identity is "circulated by a system of significations oppressive to women" (p. 154). Identity is a social construction and Edna's identity is socially instituted and discursively produced. Edna wishes to create a new and different role / identity for herself which falls outside the restricting cultural forces and the complex web of male discourses. The naturalist overtones of the plot and the setting where women like Edna are brought up show the difficulty or impossibility of change and making a new identity not in line with male-defined codes.

Feminine weakness is part of the constructed female identity. Edna is not a feminist. She is weak to want, possess or change anything. As a social outcast unable to make peace with the patriarchal society, she is neither able to remove herself from her former life nor powerful to win over the society. This signifies that any attempt in making a female logic is doomed to failure. Many critics have seen this otherness as a result of physiological lack but De Beauvoir (1961) goes even further to state that "woman has no autonomous history" (p. xix). This reduces the woman to an imitation or image lacking originality shown in many passages in which Edna is compared with children: Edna thinks of "the time I have lost splashing about like a baby" (Chopin, 1899, p. 37). This is why I do not agree with Streater (2007) who argues that Edna's return is a return to "the womb and the lost mother" (p. 415). Edna is so weak that is not able to do such a heroic action as making a critical return. Edna is not able to have everlasting resistance; she cannot become an artist either, for this means liberation from the complex discursive traps set in language and the practices of the society. Edna's challenge is more like being caught in a vicious cycle where the sea is a father figure that dissolves her for violating the father's law. Her challenging her father's Presbyterianism and Christianity, and escape from her husband and the Grand Isle result in just going back to the male sea. In the sea Edna's "strength was gone." Edna looks "into the distance" and an "old terror flamed up for an instant." Edna hears "her father's voice" (Chopin, 1899, p. 157). Edna's eyes are opened to a world she had never known; she never gained knowledge about; and she had never power over.

One way Edna adopts in order to express her identity and own her mind and body is the expression of her pleasureChopin's bold and sensuous descriptions are noteworthyand her attention to beauty and music: "Edna had a sensuous susceptibility to beauty" (p. 18) and she calls herself "very fond of music" (p. 34). This is precisely the reason Streater knows Adele as an active and passionate feminist who resists those conventions that suppress female beauty. After Edna is more concerned about her appearance she selects her partners as a reaction to the very process of interpellation. Selecting Alcee and Robert is, to the reader's surprise, a heroic act of defying the ideology of female passivity but the point to ponder is to what extent she will be able to change male look, and do something to change Robert's view of her as anything other than a sexual object. Edna thinks "the touch of the [masculine] sea is sensuous, enfolding the body in its soft, close embrace" (p. 18). Extramarital relationships with Alcee or Robert are not promising, for the climax of such relationships is no more than a vicious cycle: a requiring to become the good wife and mother she used to be. Before her suicide Edna thinks that "there was no one thing in the world that she desired. There was no human being whom she wanted near her except Robert; and she even realized that the day would come when he, too, and the thought of him would melt out of her existence, leaving her alone." Chopin continues that "the children appeared before her like antagonists who had overcome her; who had overpowered and sought to drag her into the soul's slavery for the rest of her days" (p. 155). It is significant to note that the same as the Lady of Shallot who writes her name upon the boat and dies while moving on water, and who is praised by Sir Lancelot for her sensual beauty, Edna decides to defy the orthodoxy though she knows that a curse will fall upon her, dies in water and would probably be regarded as a beautiful object.

The new roles - artist and Robert's lover-Edna adopts cannot be sustained in a society that itself interpellates roles and identities. By experiencing new roles, Edna is neither able nor willing to go back to her former roles. Since she is not allowed to stay in these roles, her death is not hard to guess. Edna's seeking refuge in art means creativity and emotion. She practices intellectual and physical conquest in her learning to paint and swim respectively. The role that the society prescribes to women is "defined in relation only to marriage and to motherhood" (Gray, 2004, p. 57). Adele, accordingly, is known as the perfect mother but with no sense of self. Ramos (2010) believes Edna's problem "not so much a matter of how many available roles there are to 
choose from, but of how to fight for and dedicate oneself to $\ldots$ any of those roles (p. 154).

To reveal more about Edna's character, Chopin has juxtaposed the nurse - a "Quadroon"-with Edna. The nurse "knows her position in the world, and this contrasts sharply with Edna's realization of her own position" as an individual or human being (Powell, 2009, p. 277). Like Adam and Eve who were expelled from paradise for gaining knowledge, Edna is dissolved in the sea for violating the fatherly law of not gaining knowledge or power. After making sure that new roles are not sustainable, and a new position is hard to achieve, Edna finds death as the only way of liberating herself from the society-defined roles and positions that are socially constituted. One's position is ideologically made in the society, and Easthope (1991) defines ideology as "meaning which is socially constituted" and "it is social not individual being which determines consciousness." Ideology "conforms to the interests of those from whom it comes" (pp. 130-131).

\section{CONCLUSION}

Scofield (2006) states that The Awakening is about "female sexual self-discovery" and names "the emotional liberation of women" as a persistent theme in Chopin (p. 98). The idea of liberation or rebirth must be rethought, for Chopin has shown the annihilation of Edna. Edna's being resistant to ideologically-made constraints, and being subject to those constraints have made some critics dissatisfied with the conclusion. Such a critic as Spangler (1970) believes in the inconsistency between Edna's character and the final act. He believes that the final part "undercuts the otherwise superb characterization of the protagonist" (p. 250). Perhaps what these critics see is that Edna risks her freedom in which she might be able to express herself.

Of course one cannot be so strict with the idea of marginal expression or suppression. However, one cannot miss Chopin's anxiety about herself and women for whom there may be no hope and salvation. Chopin begins a question by ending her novel: Is awakening really possible or is it just an illusion? Perhaps the answer can be found in Foucault's words that "just because women are excluded from centres of cultural production, they are not left free to invent their texts" (as cited in Walkowitz, 1989, p. 30). Edna is a cultural sideline, a marginalized subject and the construct of the very patriarchal system and culture to which she shows resistance. Edna is outside centre but not outside power, and this makes female awakening a very complex issue to explore since both men and women shape and are shaped by culture. Chopin's look is more Kristevaesque where she shows the masculine sea not allowing a liberated, new-born, and different Edna to exist.

\section{REFERENCES}

Althusser, L. (1998). Ideology and ideological state apparatuses. In J. Rivkin, \& M. Ryan (Eds.), Literary theory: An anthology (pp. 294-304). Malden: Blackwell Publishers,

Bradley, P. L. (2005). The birth of tragedy and the awakening: Influences and intertextualities. Southern Literary Journal, 37(2), 40-61.

Butler, J. (2007). Gender trouble: Feminism and the subversion of identity. New York: Routledge.

Card, C. (Ed.). (2003). The cambridge companion to Simone De Beauvoir. Cambridge: Cambridge UP.

Chopin, K. (1899). The awakening and selected short stories. New York: Bantam Classic.

Church, J. and Havener, C. (2008). The "lady in black" in Chopin's the awakening. Binghamton University Heldref Publications, 196-197.

De Beauvoir, S. (1961). The second sex. (H. M. Parshley, Trans.). New York: Bantam/ Alfred A. Knopf.

Easthope, A. (1991). Literary into cultural studies. New York: Routledge.

Gates, H. L. (1991). Critical fanonism. Critical Inquiry, $17(1), 457-470$.

Gray, J. B. (2004). The escape of the "sea": Ideology and the awakening. Southern Literary Journal, 37(1), 53-73.

Lane, R.J. (2006). Fifty key literary theorists. New York: Routledge.

Loomba, A. (2000). Colonialism/postcolonialism. London: Routledge.

Parry, B. (1987). Problems in current theories of colonial discourse. Oxford Literary Review, 9(1-2): 27-58.

Parvulescu, A. (2005). To die laughing and to laugh at dying: Revisiting the awakening. New Literary History, 36(3): 477-495.

Pizer, D. (Ed). (1999). The cambridge companion to American realism and naturalism: Howells to London. Cambridge: Cambridge UP.

Powell, T. (2009). Chopin's the awakening. Kennesaw State University Heldref Publications, 276-279.

Ramos, P. (2010). Unbearable realism: Freedom, ethics and identity in the awakening. College Literature, 37(4): 145-166.

Rivkin, J., \& Ryan, M. (Eds). (2000). Literary theory: An anthology. Oxford: Blackwell Publishers.

Scofield, M. (2006). The cambridge introduction to the American short story. Cambridge: Cambridge UP.

Spangler, G. M. (1970). Kate Chopin's 'the awakening': A partial dissent. Novella Forum on Fiction, 3(3): 249255.

Streater, K. M. (2007). Adele Ratignolle: Kate Chopin's feminist at home in the awakening. The Midwest Quarterly, 48(3): 406-416.

Walkowitz, J. (1989). Patrolling the borders, feminist historiography and the new historicism (exchange and seminar). Radical History Review, 43(1): 23-43. 